\title{
ANALYSIS OF THE LOW PERFORMANCE OF TESTS FOR DIAGNOSIS AMONG IMMUNOMEDIATED RHEUMATIC DISEASES PATIENTS WITH SUSPECTED CASE OF COVID-19 IN MANAUS/AMAZONAS
}

Gabriella Bacellar Marques ${ }^{1, \star}$, Samuel Elias Basualto Dias ${ }^{1}$, Vitória Miki Pang Takatani ${ }^{1}$, Clara Pinheiro Martins ${ }^{1}$, Cecília Tizatto Barroso ${ }^{1}$, Joelma Moreira Belas Torres ${ }^{1}$, Bárbara Letícia Costa Corrêa ${ }^{1}$, Gabriela Alarcón Alcântara ${ }^{1}$, Bruna Borges Santos ${ }^{1}$, Gabriel Antônio de Lima Cerqueira ${ }^{1}$, Bruna Guimarães Dutra ${ }^{1}$, Laura Ribeiro Aref Kzam ${ }^{1}$, Andrezza Mendes Franco ${ }^{1}$, Helena Lúcia Alves Pereira ${ }^{1}$, Sandra Lúcia Euzébio Ribeiro ${ }^{1}$

1.Universidade Federal do Amazonas, Manaus (AM), Brazil.

*Corresponding author: gabibacellar07@hotmail.com

\section{BACKGROUND}

The number of confirmed cases of the disease caused by severe acute respiratory syndrome coronavirus 2 (SARS-CoV-2) is a crucial data for understanding the dimension of the pandemic. In Brazil, the Brazilian Ministry of Health (BMH) recommended test only in severe cases. The BHM considers confirmed case of coronavirus disease 2019 (COVID-19): the flu-like-symptoms episode plus contact with confirmed COVID-19 patient (14 days prior to the symptoms). The objective of this study is to demonstrate that the number of immune-mediated rheumatic diseases (IRD) patients with suspected case of COVID-19 is higher than that detected by limited testing in Manaus/Amazonas.

\section{MATERIALS AND METHODS}

Prospective observational study, based on the analysis of data from patients with IRD of Project Mário Pinotti ll, organized by Brazilian Society of Rheumatology, locally in Manaus/Amazonas. It was analyzed: sex, age, flu-like-symptoms (asthenia, headache, coryza, diarrhea, dysgeusia, dyspnea, sore throat, fever, nausea, anosmia, dizziness, cough and vomiting), contact with suspected or confirmed case of COVID19, diagnosis of SARS-CoV-2 infection confirmed by laboratory (RT-PCR, serology or rapid test). The study was approved by Ethical committee.

\section{RESULTS}

A total of 311 patients with IRD were followed from April 28 to September 17,2020. The mean age was $39.14 \pm 11.66$ years, $293(94.2 \%$ ) were females and 18 (5.79\%) males. Presented flu-like-symptoms 174 patients (55.9\%), of these 52 (29.9\%) reported recent contact with suspected or confirmed case of COVID-19. Only four (2.3\%) confirmed the diagnosis with positives RT-PCR. After a minimum interval of 14 days from the first episode, 65 (20.9\%) reported a second episode of flu-like-symptoms, of these 20 (30.7\%) reported recent contact with suspected or confirmed case of COVID-19. Only 6 (9.2\%) confirmed the diagnosis: two rapid tests, three serology and one RT-PCR positives. After a minimum interval of 14 days from the second episode, 15 (4.8\%) reported a third episode of flu-like-symptoms, of these $8(53.33 \%)$ reported recent contact with suspected or confirmed case of COVID-19. Only three (20\%) confirmed the diagnosis: two serology and one RT-PCR positives.

\section{CONCLUSION}

The study demonstrates that testing for suspected cases of COVID-19 is low. Testing to estimate the real prevalence of COVID-19 in this population is important, due to chronic disease and the use of immunosuppressants, this group could evolve with more severe forms of infection. We also observed some patients who reported more than one episode of flu-like-symptoms suggestive of COVID-19, such as described in the literature. According to this, the hypotheses are reinfection or reactivation by SARS-CoV-2, in which immunosuppressive factors could contribute to impair viral clearance.

\section{REFERENCES}

1. Definição de Caso e Notificação [Internet]. Ministério da Saúde. Coronavírus (Covid-19) [cited 2020 Sep. 15]. Available from: https:// coronavirus.saude.gov.br/definicao-de-caso-e-notificacao

2. Gousseff M, Penot P, Gallay L, Batisse D, Benech N, Bouiller K, et al. Clinical recurrences of COVID-19 symptoms after recovery: viral relapse, reinfection or inflammatory rebound? J Infect. 2020;81(5):816-46. https://doi.org/10.1016/j.jinf.2020.06.073

3. Prado MF, Antunes BBP, Bastos LSL, Peres IT, Silva AAB, Dantas LF, et al. Analysis of COVID-19 under-reporting in Brazil. Revista Brasileira de Terapia Intensiva. 2020;32(2):224-8. https://doi.org/10.5935/0103-507X.20200030 